\title{
The Public Debt of Latvia: Short-Term and Long-Terms Aspects
}

\author{
Staṇislavs Keišs ${ }^{1}$, Alla Seregina ${ }^{2}$ \\ ${ }^{I}$ University College of Economics and Culture, Latvia \\ ${ }^{2}$ Transport and Telecommunication Institute, Latvia \\ E-mails: ${ }^{1}$ s.keiss@eka.edu.lv(corresponding author); ${ }^{2}$ vik2906@inbox.lv
}

Received 10 February 2017; accepted 07 April 2017

\begin{abstract}
The article investigates the structure and dynamics of public debt of Latvia for the period from 2006-2016 year. The relevance of the study long-term effects of public debt on the economy of Latvia is predetermined by a significant increase in its volume of low GDP growth rates in recent years. This article discusses conceptual approaches and criteria for evaluation of the public debt. An analysis of the main reasons for the growth of public debt of Latvia after joining the EU, considers its specific characteristics and consequences as compared with the more developed EU countries on the basis of these annual reports of Latvia Treasury over the past ten years. Analysis of the structure of the debt of Latvia on maturity shows that an effective public debt management necessarily involves consideration of the long-term effects of the growth of public debt to the public. High level of the external indebtedness in the structure of Latvian public debt is a factor of the growth of "debt overhang" even following Maastricht criterions of public debt. As a result of the research is justification of differentiated approach necessity to the evaluation of public debt with considering of intertemporal effects.
\end{abstract}

Keywords: public finances, government debt, intertemporal effect, borrowing in international markets, consolidated budget financial balance.

JEL Classification: F34, F43, F62.

Conference topic: Contemporary Issues of Economics and Management Studies: Problems and Perspectives.

\section{Introduction}

The public debt of Latvia in 2016 amounted to 8.913 billion EUR, which corresponds to 35,6\% of GDP. In the EU countries, the average share of public debt exceeds $80 \%$ of GDP, compared with the same indicator of the public debt of Latvia formally not serious. However, if we consider the public debt structure and schedule of future payments, the estimation will be slightly different. In the government debt structure of Latvia's foreign debt is $83 \%$ and if the 2016 payments should amount to 400 million EUR, in 2020 - 1.3 billion EUR and in 2021 - 1.4 billion EUR (Valsts kase. Ceturkšna biletens 1C / 2016). Naturally to make such payments due to the current budget is impossible and would require new loans.

The concept of relative safety for the economy of the budget deficit through the issuance of debt and the increase in public debt has been and remains the predominant both in economic theory and in modern economic policy. The main argument in favor of debt financing is to reduce the risk of inflation. As for the need to pay for the increasing debt, it is a widespread view according to which the state will always be able to repay previously issued obligations by issuing new debt and eliminate the threat of default (Brummerhof 2002).

However, the unstable state of the financial markets in recent years and the rapid growth of public debt levels in most industrialized countries contribute to increasing skepticism about the ability to assess the debt without serious consequences for the economy to solve the problem of public finances.

In assessing the impact of the growth of public debt the most important for the country is the intertemporal aspect of the problem, namely, whether and to what extent the public financial burden be shared by future generations. The extent of the impact of public debt on future generations who will have to implement the return of credits depends on the sources of the public debt. If the financing of public expenditure at the expense of domestic debt, then there is the movement of resources from the private sector and government loans do not have an impact on the burden of future generations. Future generations have macroeconomically balanced the requirements and obligations. Payment of interest and repayment of loans are the transfer of property rights between the economic entities groups. If the taking of loans made abroad, the future generation will be obliged to pay the sum of overseas loan repayment and interest that would reduce the resources used within the country.

(C) 2017 S. Keišs, A. Seregina. Published by VGTU Press. This is an open-access article distributed under the terms of the Creative Commons Attribution (CC BY 4.0) License, which permits unrestricted use, distribution, and reproduction in any medium, provided the original author and source are credited. 
Future taxpayers are responsible for servicing the public debt, and it is necessary for this the analysis and account of intertemporal effects for Latvian economic.

Mentioned premises predetermine the targets, methods and the structure of the research.

The target of the research is justification of improving the management of public debt of Latvia with considering of intertemporal effects.

The analyses of the existing practice and problems of the Latvian public debt management is conducting on the base of selected methodology using following methods of theoretical and empirical research: factor analysis, structural-functional and system analysis and also comparative, statistical and analytical methods of research.

So far as the problem of the public debt has different level character and is evaluating differently by representatives of varioustrend of the economic thought, therefore firstly is necessary to identify the methodological basicsthat are explored. In theoretical section of the article are considering the existing approaches to the public debt analysis, on their basis is arranging further analysis of dynamic and the structure of the public debt of Latvia, the factors of it's formation process and the efficiency of management. The analysis of the theoretical aspects and practice of management by public debt of Latvia allows formulating the sentences of necessity to the accounting of intertemporal effects of the public debt.

\section{Conceptual aspects of the problem of public debt}

The complexity of the analysis of public debt issues predetermined by the fact that the evaluation of this multifaceted economic phenomenon to a large extent depends on the position of the researcher. There are three groups of researchers associated with the problems of the state debt. The first group - it's an academic economic science, developing formal models, which are part of the debt of the theory of the theory of public finance and fiscal theory (Dickertmann, Reichert 2010; Greiner 2011; Krugman 2012; Reinhart, Rogoff 2010; Bordo et al. 2009; Konrad, Zschapitz 2010). The second group - macroeconomists working in international economic organizations such as the International Monetary Fund, World Bank, Organization for Economic Cooperation and Development. These organizations are the link between fiscal theory and fiscal policy. In recent years, the activities of international organizations affect the magnitude of the external debt (Aizenman et al. 2007; Cecchetti et al. 2011; Checherita et al. 2012; Presbitero 2016; Krugman 1989). The third group - it is a state machine, or professional bureaucrats' particular country, developing and implementing fiscal policy (Keišs, Kazinovskis 2014; Ryczewski 2011; Reinhart, Rogoff 2009; Stalder 1997).

In today's world, the national debt is an important source of financing budget deficits. This is due to the specific economic conditions and a particular country it is difficult to clearly determine the effect of public debt on economic development. The ambiguity of this phenomenon determines the significant differences in the estimates of the representatives of the public debt of various directions of economic theory.

With the development of economic thought views on its importance for the economy of the country ranged from complete rejection characteristic of a large part of the representatives of the classical economic theory, to Keynesian consideration of a debt as a necessary component of the stabilization of public policy.

The founders of classical political economy of Adam Smith and David Ricardo evaluated the national debt as a purely negative phenomenon because the state diversion of resources from the private sector of the economy leads to a reduction in investment and inhibits economic development. Adam Smith compared the national debt with one-way street, entering which one cannot turn back. Smith believed that progressive debts in the long run may destroy all the great nations of Europe. Ricardo called the national debt one of the worst disasters. Later representatives of the classical direction, Thomas Robert Malthus, John Stuart Mill, Pierre Paul Leroy Beaulieu attitude to debt is not so clear. Malthus considered debt financing as a factor in the increase in demand, Mill saw no harm in the expansion of foreign capital due to increased public demand for it, Leroy Beaulieu considered debt a positive development if the funds are used to finance public works. A similar view is shared by modern neo-classical, in particular, Robert Barro (Barro 2008).

Fundamentally different role for government debt is in the Keynesianism concept. The main purpose of Keynesian economic policy is to ensure full employment by stimulating effective demand. Such an expansion of aggregate demand involves the expansion of public expenditure and, consequently, an increase in the state budget deficit, the coating of which leads to an increase in government debt. However, since the ultimate goal is to stabilize the economy, in the future economic growth will reduce the deficit and debt. That is, the budget deficit is not terrible in the context of economic stabilization and debt does not threaten public finances in the long term. This position is shared by both the founders of Keynesianism- Keynes, Domar, Hansen, and their modern successors (Stiglitz 2010; Feldstein 2011). Therefore, in the early post-war decades, almost all industrialized countries have been stabilizing fiscal policy without particularly afraid of deficits and debt. However, by early 1980 - years stabilization policy has ceased to be effective, the cause of which was stagflation. The combination of a stagnating business, high unemployment and high inflation made problematic the further use of the stabilization principles of fiscal policy. In addition, Keynesianism was subjected to harsh criticism from representatives of monetarist and rational expectations theory, believing that state regulation of the economy cannot be effective in principle, because it violates the 
operation of the market mechanism. And because in the modern policy of economic liberalism, the central role given to the monetarist control mechanisms, the fiscal policy virtually has no theoretical justification. Development of the economical thought showed that a problem of the public debt is not in necessity to use borrowings. The main question is what is the target and how big could be the amount of borrowed money and what are the consequences of the debts for the economy.

Some of main positive aspects of debt financing are:

- Opportunities of using external resources for stimulate the production, to increase export of products and services, increase of employment, growth of business and population incomes and increase of taxes arrival in the budget of government;

- Straitening of international cooperation with borrowing from international financial organizations and in the international finance markets, and also straightening of external government credits and guaranties;

-Opportunities to lay out the recourses not only in gold exchange resources, but also in the government debt obligations, that is smoothing fluctuation of finance markets.

The main negative consequences of the growth of debt are:

- Possible decrease of activity of investments because of "displacement effect", as private investments are decreasing in the result of redistribution of funds in favor to the obligations of the government debts;

- The maintenance of external debt leads to increase of level of national savings;

- In the result of increase of external debt, the burden of payment of a debt is shifting to the next generations;

- The appearance of a threat of debt crisis in case of ill-conceived politics in the field of government debt management;

- Payment of the percents and the main sum of debt raises the outflow of resources abroad.

Thus, in the 2000s, the views of economists on fiscal policy and the assessment of public debt are quite chaotic. According to Philip Aristisa and Malcolm Sawyer "in the past two decades, macroeconomic policy has suffered a major shift in the sense of the relative importance of the monetary policy and fiscal policy, because of which the first has become more important, while the second has lost value as that of her barely remembered" (Arestis, Sawyer 2005).

However, the rejection of the stabilization of fiscal policy to counter inflation not only has not led to a reduction in public debt, on the other hand the growth of public debt reduction in the past two decades has acquired spontaneous character in many countries. As in almost all countries, there is the outpacing growth of debt compared to GDP growth, the debt problem is global in nature, and the International Monetary Fund has become a leading centre for the analysis of long-term sustainability of public finances. Fiscal policy is now almost never used for the purpose of short-term stabilization, and is subject to the preservation of long-term fiscal sustainability of the state. The main thing is to prevent a default. The general view is that we should not balance the budget and keep the deficit and debt in certain limits.

For the EU, these criteria were enshrined in 1997 in the Stability Pact and growth, which were prescribed restrictions on the level of the budget deficit (not more than 3\% of GDP) and the amount of public debt (less than $60 \%$ of GDP). These limits are referred to as the Maastricht criteria or convergence criteria.

The global financial crisis has led to a need for more radical measures to resolve the budget deficits of EU member states. In this connection, it was adopted the Treaty on Stability, Coordination and Governance (Fiscal Pact), which entered into force on 1 January of 2013.

Fiscal policy of Eurozone countries is obliged to comply with the criteria prescribed in the Treaty, and the criteria are recommendations for the rest of the EU members. In contrast to the rules which applied under the Stability and Growth Pact, the measures prescribed in the Fiscal Pact, the so-called "golden rule", should be prescribed at the national level in the constitution or the documents, bearing a constitutional nature. "The Golden Rule" includes the following requirements: a structural budget deficit should remain within $0.5 \%$ of nominal GDP, but in countries with a level of public debt to GDP well below $60 \%$ this figure can be increased to $1 \%$. In the case of deviations from the established norms a fine of $0.1 \%$ of GDP is imposed for the state, and the proceeds are sent to a single stabilization fund, and can be used to stabilize the situation in the fined country. At the same time a country imposed "automatic correction mechanism" designed individually for each case, the purpose of which is to develop the necessary programs to reduce excessive budget deficits. (Treaty on Stability, Coordination and Governance in the Economic and Monetary Union, 2012).

Thus, the Maastricht criteria, and additional long-term fiscal limitations prescribed in the Fiscal Pact, primarily aimed at long-term sustainability of public finances, but prevent the use of fiscal policy for the purpose of short-term stabilization. These two divergent effects - one short, the other long-term - make up the main contradiction of modern fiscal policy. The absence of effective mechanisms to stimulate economic growth exacerbates the debt problem. 


\section{Problems of public debt management in Latvia}

Indicators of structure and dynamics of growth of public debt of Latvia after joining the EU clearly reflect the contradictions of modern fiscal policy.

Table 1. The Debt of Latvian Central Government (million EUR)

(Source: Valsts kase. Reports on Central Government Debt Management 2006-2015)

\begin{tabular}{l|c|c|c|c|c|c|c|c|c|c}
\hline \multicolumn{1}{c|}{ Indicator } & 2006 & 2007 & 2008 & 2009 & 2010 & 2011 & 2012 & 2013 & 2014 & 2015 \\
\hline $\begin{array}{l}\text { Consolidated budget } \\
\text { financial balance, million } \\
\text { EUR }\end{array}$ & -78.7 & 134.2 & -613.4 & -1224 & -146.7 & -635.6 & 130 & -5.8 & -313.0 & -346.8 \\
\hline$\%$ of GDP & -0.5 & 0.7 & -2.6 & -6.6 & 0.4 & $-3,1$ & 0.6 & -0.02 & -1.3 & $-1,4$ \\
\hline $\begin{array}{l}\text { General government debt, } \\
\text { million EUR }\end{array}$ & 1702.4 & 1657.1 & 3973.6 & 6135.7 & 7257.1 & 7641.1 & 8074.3 & 8876.0 & 9689.8 & 8871.7 \\
\hline$\%$ of GDP & 7.3 & 8.9 & 17.1 & 32.9 & 39.9 & 37.8 & 36.7 & 38.2 & 41.4 & 34.5 \\
\hline $\begin{array}{l}\text { Gross borrowing in } \\
\text { government domestic } \\
\text { securities auctions, } \\
\text { million EUR }\end{array}$ & 111.3 & 177.4 & 212.6 & 387.7 & 373.7 & 754.0 & 212.3 & 269.8 & 289.3 & 244.4 \\
\hline $\begin{array}{l}\text { Borrowing in international } \\
\text { markets, million EUR }\end{array}$ & 129.7 & 163.0 & 43.1 & 904.4 & 145.6 & 62.8 & 531.9 & 465.9 & 592.6 & 425.3 \\
\hline $\begin{array}{l}\text { Issued state budget loans, } \\
\text { million EUR }\end{array}$ & 1915.6 & 900 & 610.1 & 266 & 315.0 & 373.0 & 493.3 \\
\hline $\begin{array}{l}\text { Outstanding state guarantees, } \\
\text { million EUR }\end{array}$ & 1409.1 & & & & & & & & \\
\hline
\end{tabular}

Data analysis treasurer reports on public debt management in the past ten years shows that the formal observance of the Maastricht criteria (the public debt does not exceed $60 \%$ of GDP), the situation of public finances is difficult to assess as stable, especially in the long term. As you can see, the dynamics of change in debt ratios is intermittent in nature, reflecting the significant impact on the value of public debt to external factors. Until 2008, the situation of public debt in Latvia was relatively stable: the annual issuance of government debt mainly corresponded to the value of the current budget deficits, in fact in 2007 the public debt of Latvia had the accumulated amount of budget deficits for the previous 10 years. In the structure of government debt at that time, foreign loans accounted for half of the debt, the second half was domestic debt. The sharp jump in the public debt crisis going on in 2008 and 2009 , but this increase has caused not only by an increase in the budget deficit, but mainly to the provision of support to the banking sector of the economy. In December 2008 the IMF mission made an agreement with the government of Latvia on receipt of financial support from IMF, European Commission, World Bank, European Reconstruction and Development Bank and several EU member states in total amount of 7.5 billion EUR. The loan from IMF will be in amount of 1.7 billion EUR, from European Commission - 3.1 billion EUR, from the World Bank - 400 million EUR. The loan till 1.8 billion EUR will be granted from Sweden, Denmark, Finland and Norway together. The financial support will include also Czech Republic, Poland and Estonia with 100 million EUR contribution from each. Loan till 200 million EUR is expected from European Reconstruction and Development Bank (Report on Central Government Debt Management, 2008). This program was designed for three years, and in late 2011 the international creditors committee commended the Government of Latvia on financial stability as a fairly successful.

Table 2. Total financing provided by international lenders (bn EUR)

(Source: Valsts kase. Report on Central Government Debt Management 2011)

\begin{tabular}{|c|c|c|c|c|c|c|c|c|}
\hline \multirow[b]{2}{*}{$\mathrm{EC}$} & \multicolumn{2}{|c|}{$\begin{array}{c}2009 \\
\text { Planned Received }\end{array}$} & \multicolumn{2}{|c|}{$\begin{array}{c}2010 \\
\text { Planned Received }\end{array}$} & \multicolumn{2}{|c|}{$\begin{array}{c}2011 \\
\text { Planned Received } \\
\end{array}$} & \multicolumn{2}{|c|}{$\begin{array}{c}\text { Total } \\
\text { Planned Received }\end{array}$} \\
\hline & 2.9 & 2.2 & 0.1 & 0.7 & 0.1 & 0 & 3.1 & 2.9 \\
\hline Nordic Countries & 0.1 & 0 & 1.8 & 0 & 0 & 0 & 1.9 & 0 \\
\hline IMF & 1.2 & 0.8 & 0.4 & 0.3 & 0.1 & 0 & 1.7 & 1.1 \\
\hline World Bank & 0.2 & 0.2 & 0 & 0.1 & 0.2 & 0.1 & 0.4 & 0.4 \\
\hline Others & 0.1 & 0.1 & 0.3 & 0 & 0 & 0 & 0.4 & 0.1 \\
\hline Total & 4.5 & 3.3 & 2.6 & 1.1 & 0.4 & 0.1 & 7.5 & 4.5 \\
\hline
\end{tabular}


As the data in the above table, from the planned 7.5 billion EUR 4.5 billion EUR has been used by Latvia. Borrowing in international markets on the one hand, helped to reduce the cost of debt, but on the other hand, led to a significant increase in the share of external debt. By the end of 2008, placing of promissory notes of domestic debt occurred in the conditions of rather high inflation, so the required rate of return on such liabilities exceeded $10 \%$. In general, in $2008,40 \%$ of the debentures were issued in lats, and $39 \%$ were short-term liabilities with a maturity of up to one year and $52 \%$ - with a term of up to 3 years. Under these conditions obtaining of loans on international markets by $5 \%$ helped to reduce the cost of debt, but the share of domestic debt has declined to $19.7 \%$ by the end of 2009 , and since then the share of external debt has remained at $80 \%$.

Stabilization of the financial system and the entry into the euro zone helped to improve the credit rating and since 2014 Latvia independently places Eurobonds.

On 14 January 2014, Latvia successfully priced seven-year bonds in the amount of one billion euro with a fixed interest rate of $2.625 \%$. The issue was oversubscribed more than four times. It allowed to refinance EC loan which was repaid in March with lower costs (fixed interest rate of 3.125\%) On 24 April Latvia managed to successfully issue ten-year bonds in the amount of one billion euro with a fixed interest rate of $2.875 \%$

In 2015, Latvia ensured a supply of benchmark term securities by issuing 10-year bonds in the amount of EUR 500 million with a fixed interest rate of $1.375 \%$ per year. The fixed interest (coupon) rate of the new 5-year euro bonds that were simultaneously priced in December 2015 was $0.50 \%$. In May 2016 Latvia issued 20-year bonds with a coupon rate of $1.375 \%$, the volume of 650 million EUR. In general, in the first half of 2016 debts payments amounted to 774 million EUR and new loans 1448 million EUR. The total amount of debt at the same time increased to 9.153 billion EUR (Valsts kase. Ceturkšṇa biḷetens 2C / 2016).

On September 2016, due to the favorable conditions in the international capital markets, Latvia issued a new 10 year bond amounting EUR 650 million. The coupon was set at the historically lowest level 0,375\% (yield 0,456\%). Demand for Latvia's new bonds exceeded 2,6 times the issuance size. The decision for the issuance was taken when rates are at its historically lowest levels, thus allowing us to lock-in to a very low interest rate for the long-term borrowing. The high demand for bonds demonstrated the trust of high quality investors towards Latvia as the low credit risk Issuer. The issuance was well received from more than 90 investors. Investors were mainly from Europe (Germany, United Kingdom, Scandinavia and other continental Europe). Joint Lead Managers were Barclays, Goldman Sachs and JP Morgan.

On February 2017, Latvia successfully priced dual-tranche Eurobonds in the international capital markets in an aggregate amount of EUR 650 million, covering most of Latvia's financing requirements for 2017. The 30-year Eurobonds represent the longest tenor issued by Latvia. The 30-year tranche priced at a coupon of $2.250 \%$ (yield $2.330 \%$ ), in a new benchmark issue size of EUR 500 million. Simultaneously, Latvia tapped its $0.375 \%$ Eurobonds maturing October 7, 2026, increasing the outstanding amount of these bonds by EUR 150 million at a yield of $1.062 \%$. Demand for Latvia's Eurobonds exceeded issue size by 1.6 times in the case of the 30-year Eurobonds and by 2.8 times in the case of the tap. The Eurobonds were well received by approximately 50 investors for each tranche. Investors were mainly from Europe (Germany, Austria, United Kingdom and other countries). The Joint Lead Managers were Deutsche Bank, Goldman Sachs and Société Générale (Valsts kase 2017).

November 25, 2016, the international credit rating agency $S \& P$ Global affirmed its 'A-' long term foreign and local currency sovereign credit ratings on the Republic of Latvia. The outlook is set stable. S\&P Global ratings on Latvia remain supported by the country's generally sound institutional effectiveness, modest general government deficits, and declining net public debt burden. The ratings are constrained by relatively low GDP per capita, longterm challenges associated with a declining population, and external financing risks, including from high levels of non-resident deposits in the banking system. S\&P Global outlines, the country's institutional settings remain comparatively strong and they expect the generally effective governance to continue given that the key goals are shared across the political spectrum. The stable outlook for rating reflects the balance between Latvia's potential for better-than expected fiscal performance over the next two years, and longer term demographic challenges coupled with some balance of payments vulnerabilities. On November 4, a similar decision on the Latvian credit rating for long-term local and foreign currency retention of "A-" with stable outlook announced the international rating agency Fitch Ratings.

On January 2017, Japanese credit rating agency R\&I changed Latvia's credit rating outlook to positive from stable. R\&I has affirmed the Foreign Currency Issuer Rating at BBB + . Credit rating agency positively estimates Latvia's stable financial system adherence to disciplined fiscal management, stable political climate and economic development. Increase of economy's resilience to external shocks is estimated positively. R\&I point out Latvia`s ability to maintain a positive economic development despite trade downturn with Russia. R\&I will upgrade the rating if Latvia can confirm a sound fiscal position and stable financial system even when external conditions change (Valsts kase 2017).

Thus, to date, the public debt management policy is largely confined to refinance existing debt. The current state of financial markets and an increase in 2016 of long-term credit rating of Latvia to the "A-" level create opportunities for future refinancing. 
However, be aware that the use of mechanisms to refinance depends on the debt structure. In the structure of the debt of the major industrialized countries, the major part is the domestic debt, respectively payment of old debts by issuing new debt may continue indefinitely. According to the economists of the IMF and the World Bank, public debt management means the process of forming and implementing of a strategy for managing government obligations to increase the required amount of financial resources while maintaining an acceptable level of risk and costs, as well as compliance and other goals that the government can deliver. Debt that is badly structured for the side of payment term, currency, interest rate is an important factor which raised an economic crisis in a lot of counties. Therefore, it is necessary to develop a well-thought-out strategy of public debt managing, taking into account long-term macroeconomic consequences.

\section{Intertemporal aspects of government debt}

The impact of public debt on future generations is very ambiguous and depends on the extent of the debt, the debt structure and public debt management strategy.

Control Strategy of state debt of Latvia for the period until 2018 includes the following areas:

- to ensure borrowing in the international financial markets with public issues of government debt securities by retaining flexibility in relation to choosing the time, currencies and repayment terms of loans in order to ensure borrowing with favourable conditions;

- to maintain a constant and regular supply of government securities in the domestic financial market according to the demand in order to use the potential of borrowing in the domestic financial market and promote the functioning of the domestic financial market;

- to ensure the diversification and broadening of the base of government security investors through regular and constant dialogue and long-term work with investors and cooperation partners in order to facilitate the active participation of investors from different regions of the world in the primary placement of government securities in the international markets, thus limiting the long-term financial risks and broadening the spectra of regional borrowing possibilities

Taking into account the strategic priorities of borrowing, as well as in order to ensure the prevention of the government debt refinancing risk and the optimisation of government debt servicing costs in the medium term, during the coming years the largest share of the financial resources to be attracted will be formed by external borrowing instruments. The borrowing in international markets is planned to be based on transactions in the global financial markets, mainly by organizing public government debt security issues (Reporton Central Government Debt Management 2015).

In the context of the global debt crisis the listed trends of debt strategy are typical for the economies of most industrialized countries. However, long-term debt and the consequences for the Latvian economy the major industrialized countries differ greatly due to differences in debt structure and uses of borrowed funds.

The study long-term effects of public debt on economic growth, carried out under the supervision of Checherita and Rother, according panel data for 12 EU countries in the period 1970-2009 years has shown that the negative impact of public debt begins to manifest itself at the level of $70-80 \%$ of GDP (Checherita, Rother 2010). If while in the debt structure is a high proportion of foreign loans, the negative effects begin to appear also at a lower level of debt. Paul Krugman, in this regard put forward a "debt overhang" hypothesis (Krugman 1988, Krugman 1989. DickertmannI, Reichert 2010; Kilic 2015; Koch 2014). With the growth of the external debt of the state the cost of servicing the external debt increased so that a large proportion of the GDP goes to foreign creditors. As a result, investors have no incentive to invest in the national economy. Thus, the external "debt overhang" impedes economic growth through the reduction of private investments, as domestic and foreign investors are reluctant to provide capital due to unprofitable investments. In the presence of "debt overhang" the country is unable to repay the cost of external borrowing. Long "debt overhang" may cause the debt crisis, i.e. a default that could have devastating consequences for the country's economic potential.

The accumulation of external debt is a major threat to sustainable economic growth, rather than emissions of internal loans. Accordingly, if debt financing is necessary, the government is desirable to use domestic borrowing instruments (Piepenburg 2013; Presbitero et al. 2015; Presbitero, Panizza 2012).

In addition, in low- and middle-income countries the welfare of the population "debt overhang" imposes a limit on the rate of economic growth, even with a relatively low debt burden (Presbitero 2012; Beck 2012; Brooks 2015; Lang 2014; Muth 2014; Spethmann 2012). This is explained by the fact that, unlike the industrialized countries, in countries with low and medium level of development is extremely difficult to use borrowed funds productively and avoid capital flight, investment crowding, deterioration of the investment climate, volatile macroeconomic policies that usually accompany large government borrowing. Under these conditions, the negative consequences of the "debt overhang" displace the benefits associated with access to additional resources. Thus, the effect of the total debt on the national economy depends essentially on the specific characteristics of the country, primarily on the quality of institutions and the effectiveness of macroeconomic policies. In less developed economies, where there are unstable institutions and often inconsistent macroeconomic policies, the problem of "debt overhang" occurs even at mean 
ratio of government debt to gross output. In developed countries 'debt overhang' appears only at a very high ratio of government loans and release. Thus, weak institutions and ineffective economic policies - these are the factors that increase the negative effects of debt on growth, and accelerate the advent of the "debt overhang".

In the case of a significant increase of the public external debt, the need to service the external debt reduces the ability of the budget to finance other costs, including the development of infrastructure, health, education, which undermines the country's long-term economic growth.

In addition, in the long term, the influence of risk factors and uncertainty increases due to the following reasons:

- it is difficult to predict how the debt will affect the economy in the future, whether its restructuring will be carried out and what is the risk of default;

- in conditions of increasing of the external debt, the economic agents tend to postpone decisions of investments, even if the macroeconomic situation in the country is improving;

- opportunities for the receipt of additional borrowed funds are reduced;

- in case of a high level of debt, the investors prefer short-term projects, rather than long-term ones, what leads to decreasing in the country's investment potential, inefficient use of the economy's resources and slowing economic growth.

In the long term, it is also necessary to consider the risks of the financial markets, the most significant of which are:

- the risk of debt sustainability associated with changes in the interest rates and the cost of servicing of external debt;

- credit risk associated with the probability of failure of the borrower;

- the risk of debt restructuring, when the extension of terms of borrowing is necessary to carry out at an increased price.

Thus, at present in Latvia has been created a system of public debt management, which is able to solve only the current tasks of refinancing debts, but its activity as the main instrument of macroeconomic management is not effective enough.

The budget legislation regulates only the issues of borrowing and refinancing of external debt. At the same time, building an effective long-term external debt management system should include the development of a set of tools for conversion, redemption, and early repayment of debt, etc.

In particular, considering the very high share of external debt, it is important for Latvia to expand borrowings in the domestic market.

In addition, one of the institutional tools to improve the management of external debt is to regulate the volume of external debt through debt conversion, that is, the exchange of external debt to national assets or the repayment of debt by commodity supplies.

That is, the development of a strategically correct policy for the management of Latvia's public debt should be carried out taking into account the overall economic consequences.

\section{Conclusions}

The analysis of intertemporal aspects of government debt in Latvia reveals the contradictions of modern public debt management policy.

1. On the one hand, the situation with the government debt of Latvia in the short term seems to be pretty stable by the following criterions:

1.1. The Maastricht criteria on public debt volume and size of budget deficits formally are respected;

1.2. On this basis among EU members Latvia belongs to the group of countries with relatively stable financial system;

1.3. Confirmation of such an evaluation is improving of Latvia's credit rating in 2016 and sufficient successful placement of the latest release of long-term debt in foreign financial markets;

2. Thus, the main factors of the negative impact of public debt on capital accumulation and economic growth in Latvia for a long-time horizon are:

2.1. Deterioration of the investment climate in the country due to the high debt burden;

2.2. The cost of debt servicing absorbing a significant portion of revenues that could be directed to public investment;

2.3. Uncertainty about future fiscal policies that contributes to the deterioration of the investment climate and impeding the growth of industry.

3. Since the main focus of public debt management policy is to refinance existing debt, the only positive effect of credit enhancement is a reduction in the future cost of debt and interest payments, respectively. At the same time the volume of accumulated debt is not reduced. In addition, because external borrowing is not used for the investment in the economy, in the long-term placement of government borrowing reduces the stock of capital and economic growth. 
4. For decrease of negative consequences of the government debt for Latvian economy, changes in the structure of government debt for decrease of the external debt and increase of internal borrowings are required, and also is necessary to arrange more effective investing politics.

\section{References}

Aizenman, J.; Kletzer, K.; Pinto, R. 2007. Economic growth with constraints on tax revenues and public debt: implications for fiscal policy and crosscountry differences. NBER Working Paper 12750.

Arestis, P.; Sawyer, M. 2005. Reinventing Fiscal Policy. Levy Economics Institute and University of Leeds. https://doi.org/10.1057/9780230523708_10

Barro, R. 2008. Macroeconomics. A modern approach. Thomson / Southwestern.

Beck, H. 2012. Staatsverschuldung. Ursachen, Folgen, Auswege. Verlag Beck C. H. https://doi.org/10.17104/9783406633027

Bordo, M.; Christopher, M.; Stuckler, D. 2009. Foreign currency debt, financial crises and economic growth: a long-run view, National Bureau of Economic Research.Working Paper 15534.

Brooks, J. 2015. Grundlagen der Staatsverschuldung. Ursachen und Folgen. GRIN Verlag Gmb.

Brummerhof, D. 2002. Finanzwissenschaft. Verlag Munchen Wien.

Cecchetti, S.: G., Mohanty, G.; Zampolli, F. 2011. The real effects of debt. BIS Working Papers 352.

Checherita, C.; Baum, A.; Westphal, C.; Rother, P. 2012. Debt and growth: new evidence for the Euro area, ECB Working Paper Series 1450, July 2012.

Checherita, C.; Rother, P. 2010. The impact of high and growing government debt on economic growth: an empirical investigation for the euro area, European Central Bank Working Paper 1237.

DickertmannI, D.; Reichert, S. 2010. Öffentliche Verschuldung und die Schuldenbremse. Das Wirtschaftsstudium, H. 1, Beilage WISU-Studienblatt.

Feldstein, M. 2011. Preventing a national debt explosion, Tax Policy and the Economy 25(1). https://doi.org/10.1086/658383

Greiner, G. 2011. Economic growth, public debt and welfare comparing three budgetary rules, German Economic Review 12(2): 205-222. https://doi.org/10.1111/j.1468-0475.2010.00516.x

Keišs, S.; Kazinovskis, A. 2014. Regionālā attīstība Latvijā: administratīvi teritoriālās reformas norises gaita, problēmas, risinājumi [Regional development in Latvia: course, problems and solutions of administrative territorial reform]: monogrāfija. Rīga.

Kilic, E. 2015. Staatsverschuldung unter politökonomischen Gesichtspunkten. Peter Gmbh Lang. https://doi.org/10.3726/978-3653-05683-9

Koch, D. 2014. Wirksame Begrenzung von Staatsverschuldung: Unter Berücksichtigung (politökonomischer und ethischer Aspekte). Disserta Verlag.

Konrad, K. A.; Zschapitz, H. 2010. Schulden ohne Sühne? - Warum der Absturz der Staatsfinanzen uns alle trifft. 2. Aufl. München.

Krugman, P. 2012. Debt, deleveraging and the liquidity trap, The Quarterly Journal of Economics 127(3): 1469-513. https://doi.org/10.1093/qje/qjs023

Krugman, P. 1988. Financing vs. forgiving a debt overhang, Journal of Development Economics 29: $253-268$. https://doi.org/10.1016/0304-3878(88)90044-2

Krugman, P. 1989. Market-based debt-reduction schemes. NBER Working Paper 2587. Washington, DC.

Lang, E. 2014. Staatsverschuldung - Staatsbankrott? Springer-Verlag Gmbh.

Muth, C. 2014. Die Wirkung von Staatsverschuldung. Neutralität als Paradigma. GRIN Verlag Gmbh.

Piepenburg, A. 2013. Die Staatsverschuldung in Europa. Herkunft und Auswirkungen der bestehenden öffentlichen Verschuldung. GRIN Verlag Gmbh.

Presbitero, A. F. 2016. Lost and found: market access and public debt dynamics. IMF working paper 16/253, December 2016.

Presbitero, A. F.; Bandiera, L.; Eberhardt, M. 2015. Public debt and growth: heterogeneity and non-linearity, Journal of International Economics 97(1): 45-58. https://doi.org/10.1016/j.jinteco.2015.04.005

Presbitero, A. F.; Panizza, A. 2012. Public debt and economic growth: is there a causal effect? MoFiR working paper 65.

Presbitero, A. F. 2012. Total public debt and growth in developing countries. MOFIR Working Paper 44.

Reinhart, C.; Rogoff, K. S. 2009. This time is different: eight centuries of financial folly. Princeton University Press.

Reinhart, C.; Rogoff, K. S. 2010. Growth in a time of debt. NBER, Working Paper 15639.

Ryczewski, C. 2011. Die Schuldengrenze im Grundgesetz - Untersuchung zur nachhaltigen Begrenzung der Staatsverschuldung unter polit-ökonomischen und bundesstaatlichen Gesichtspunkten. Berlin.

Spethmann, D. 2012. Zeitbombe Staatsverschuldung. August Verlag Dreesbach.

Stalder, I. 1997. Staatsverschuldung in der Demokratie - Eine politik-ökonomische Analyse. Frankfurt a. M.

Stiglitz, J. 2010. Freefall: free markets and the sinking of the global economy. London: Penguin.

Treaty on stability, coordination and governance in the economic and monetary union [online], D/12/2. Brussels [cited 1 February 2012]. Available from Internet: http://www.kase.gov.lv/uploaded_files/Ceturksna\%20biletens_1C_2016.pdf

Valsts kase. Ceturkšņa biḷetens 1C / 2016. Centrālās valdības parāià vadība [online], [cited 16 March 2017]. Available from Internet: http://www.kase.gov.lv/

Valsts kase. Ceturkšņa biḷetens 2C / 2016. Centrālās valdības parāda vadība [online], [cited 16 March 2017]. Available from Internet: http://www.kase.gov.lv/

Valsts kase. Report on Central Government Debt Management 2011 [online], [cited 16 March 2017]. Available from Internet: http://www.kase.gov.lv/

Valsts kase. Reports on central government debt management 2006-2015 [online], [cited 16 March 2017]. Available from Internet: http://www.kase.gov.lv/ 